\title{
Menumbuhkan Sikap Menerima Perbedaan Agama dalam Perspektif Buddhisme
}

\author{
Paper ini disampaikan pada acara "Studium Generale" (Kuliah Umum) \\ dengan tema "Kebebasan Beragama dan Beribadah di Bumi Pancasila" \\ Sabtu, 30 Oktober 2010 \\ Di Universitas Kristen Satya Wacana (UKSW)
}

\section{Oleh Suranto*}

\section{Latar Belakang}

Arus globalisasi mengantarkan setiap sudut perbedaan ke dalam setiap individu. Melalui berbagai media, perbedaan tersebut sampai dalam kehidupan masyarakat. Tidak luput dari arus tersebut, agama menjadi bagian yang menunjukkan hal yang cukup sensitif dalam pergulatan religious issues dalam akhir-akhir ini. Mulai dari perseteruan yang mengarah pada kekerasan dengan mengatasnamakan agama. Sebagai contoh, tragedi HKBP dan Ahmadiyah. Hal ini menunjukkan bahwa saat ini sepertinya keragaman kehidupan agama menjadi masalah yang cukup pelik. Kepelikan tersebut tampak bahwa sampai saat ini masih sering terjadi ketidaksukaan terhadap suatu kelompok agama tertentu dan tidak luput dari tindakan kekerasan dengan mengatasnamakan suatu agama.

Menjadi suatu tantangan tersendiri bagi agama-agama besar dalam menghadapi keberagaman kehidupan beragama khususnya di Indonesia. Meskipun, Indonesia sebenarnya memiliki Pancasila dan UUD 1945 pasal 29 ayat 1 sebagai falsafah kehidupan masyarakat Indonesia dalam beragama, namun kenyataan dalam kehidupan beragama di Indonesia masih menjadi

\footnotetext{
* Dosen di Sekolah Tinggi Agama Buddha (STAB) Syailendra. Untuk responden dapat menghubungi di putta_ananda@yahoo.com
} 
bagian dari permasalahan yang ada. Permasalahan ini menjadi tanggung jawab bersama demi tercapainya keharmonisan dalam kehidupan beragama.

Agama sepertinya mendapat tantangan dalam menghadapi permasalahan yang hadir pada saat ini. Terutama masalah keragaman agama yang ada di Indonesia. Permasalahan keanekaragaman tersebut muncul ketika terdapat usaha untuk memaksa kehendak pihak tertentu. Dalam khasanah keberagaman ini, disatu sisi, agama akan tumbuh berkembang jika mampu menghadapi permasalahan yang muncul di era ini. Misalnya, setiap perkembangan agama memiliki jaman keemasan. Di lain sisi, agama akan runtuh dengan sendirinya jika tidak mampu memberikan kontribusi dalam menghadapi berbagai masalah keberagaman agama. Dorongan ini muncul, karena agama dianggap memiliki nilai lebih dan kadang menjadi instrumen legalisasi sesuatu.

Buddhisme yang menjadi salah satu bagian dari agama-agama besar yang telah berkembang di dunia memiliki tantangan tersendiri dalam menjawab tantangan keberagaman agama. Keanekaragaman agama merupakan bagian dari kehidupan ini. Dengan kata lain, keanekaragaman agama merupakan fakta kehidupan. Hal ini berarti kita sangat sulit untuk terlepas dari kondisi keanekaragaman tersebut, meskipun agama hanya merupakan salah satu elemen dari keanekaragaman itu sendiri. Berdasarkan fakta tersebut, Buddhisme melihat keanekaragaman agama merupakan suatu kondisi yang alami. Menurut Buddhisme, untuk menghadapi keanekaragaman agama atau sering disebut religious diversity bahwa berbeda penyakit akan menggunakan obat yang berbeda. His Holiness Dalai Lama juga menggunakan analogi ini dalam menanggapi religious diversity. ${ }^{1}$ Dengan

1 Dalai Lama. Ethics for the New Millennium, Riverhead Book, New York, 1999. pp. 226-227. The Dalai Lama has continued the medical analogy of the Buddha, in the case of one 
kata lain, suatu agama belum tentu cocok untuk menyelesaikan masalah pada setiap manusia. Meskipun demikian, secara umum agama bertujuan untuk membantu dalam menyelesaikan penderitaan dengan harapan untuk mencapai suatu kebahagiaan. Hal ini yang mendorong pertanyaan, bagaimana Buddhisme menghadapi keanegaragaman tersebut? Pertanyaan tersebut yang akan mengantarkan kita dalam melihat prinsip-prinsip Buddhisme dalam menghadapi perbedaan agama. Melalui prinsip-prinsip Buddhisme yang berlandaskan pada nilai cinta kasih, dapat menumbuhkan sikap menerima perbedaan agama di bumi Pancasila.

\section{Buddhisme dan Keberagaman Agama}

Keberagaman agama merupakan fakta yang tidak dapat dipungkiri dan wajar. Sudah tidak asing lagi dalam perkembangan Buddhisme bahwa keberagaman agama telah muncul dalam jaman Buddha sekitar 2500 tahun yang lalu. Buddhisme berkembang pada masyarakat yang cukup multicultural. Selain keberagaman tersebut muncul di luar Buddhisme, terdapat berbagai keberagaman yang ada dalam tubuh Buddhisme. Hal ini terjadi tidak terlepas dari berbagai faktor yang mempengaruhi keragaman agama. Perbedaan latar belakang dari suatu agama menjadi ciri khas dari masing-masing agama maupun sistem kepercayaan tertentu.

Kita tidak dapat mengelak bahwa terdapat berbagai faktor yang dapat menimbulkan masalah dalam kehidupan beragama. Salah satu faktor yang dapat mendorong terjadinya konflik dalam kehidupan beragama yaitu konsep truth claims dan pembebasan ${ }^{2}$. Setiap agama memiliki truth claims dan konsep pembebasan yang berbeda. Secara umum, truth claims dan konsep

\footnotetext{
particular patient; the suitable medicine is in fact the only medicine. However, clearly that does not mean that there may not be other medicines suitable to other patients.

${ }^{2}$ Hick, John. "The Conflicting Truth Claims of Different religions". Philosophy of Religion $4^{\text {th }}$ Edition, Prentice-Hall, 1990. p. 109.
} 
pembebasan ini menjadi bagian yang cukup krusial, ketika penganut agama tertentu mulai memaksakan kehendaknya bahwa agamanya merupakan agama yang terbaik. Untuk menanggapi persmasalahan tersebut, John Hick menjelaskan bahwa

"Every religion has a different truth claim and salvation. Generally, it is the most important thing in the problem of religious diversity. Because of truth claims, there is much violence in the world. However, the problem of conflicting truth claims, actually, is made by different religious traditions". 3 Dengan kata lain, perbedaan tradisi akan mengarahkan pada perbedaan truth claims.

Kondisi keragaman kepercayaan tersebut pernah dibahas oleh Buddha sendiri. Menurut Brahmajala sutta, Buddha menjelaskan bahwa terdapat 62 kelompok pandangan dalam memahami kehidupan ini. Setiap kelompok pandangan tersebut mengklaim dan merasa benar. Namun Buddha menunjukkan cara untuk menghadapi perbedaan pandangan tersebut dengan cara yang bijak. Cara yang telah ditempuh oleh Buddha dengan cara berdialog.

Dialog yang terbuka membawa manfaat yang positif. Salah satu sikap Buddha terhadap perbedaan pandangan tersebut terlihat ketika akan menerima siswa baru yang berasal dari kelompok kepercayaan lain terlebih dahulu Buddha melakukan dialog. Buddha tidak secara gampang mengijinkan calon siswanya untuk bergabung, tetapi Buddha selalu menyarankan untuk menyelidiki ajaran Buddha terlebih dahulu sebelum masuk menjadi siswa Buddha. Meskipun demikian, setelah menerimanya, Buddha selalu menyarankan siswanya untuk tetap menghormati guru lamanya. Hal ini terjadi karena kebenaran akan dipahami berdasarkan pengalaman setiap individu. Maka dari itu, dalam paradigma Buddhisme mengarahkan untuk membuktikan sendiri mengenai kebenaran (ehipassiko).

3 Ibid, p.109 
Nilai dari dialog ini dapat dilakukan dalam kondisi saat ini. Perlu digaris bawahi, bahwa dialog merupakan instrumen untuk menumbuhkan toleransi. Sikap toleransi ini akan muncul ketika tujuan dari dialog tidak untuk memprioritaskan indentitas agama masing-masing. Namun sebagai media secara aktif untuk menghormati setiap aktifitas dari setiap pemeluk agama atau kepercayaan tertentu untuk menjalankan aktifitas keagamaannya.

Telah dilakukan oleh berbagai lapisan masyarakat untuk melakukan dialog mengenai permasalahan tersebut. Dialog yang terbuka dan kritis tentunya akan membantu pemahaman kita dalam memahami perbedaan agama. Dialog yang ditawarkan seharusnya bersifat critical openness. Sifat dialog ini lebih cenderung melihat perspektif berdasarkan sudut pandangnya. Kadang kecenderungan dialog yang dilakukan berusaha untuk menjatuhkan pihak lain. Perlu kita melihat nilai dialog yang dilakukan oleh Buddha yang cenderung tetap menghormati kepercayaan yang lain meskipun mempunyai pandangan yang berbeda. Maka dari itu, dialog ini merupakan suatu media dalam memahami suatu perbedaan agama.

\section{Menumbuhkan Sikap Menerima Perbedaan Agama dari suatu Analogi}

Dalam paradigma Buddhisme, agama merupakan suatu alat atau instrumen dalam menjalankan kehidupan ini. Buddha menuturkan bahwa ajaran Buddha tidak lain adalah sebuah rakit yang digunakan untuk menyeberangi lautan kehidupan. ${ }^{4}$ Tidak berbeda dengan doktrin dari agama-

${ }^{4}$ Archer, Margaret S and Friends. "A Propaedeutic to a Propaedeutic on Interreligious Dialogue", by Douglas V. Porpora, Transcendence Critical Realism and God. London: Routledge, 2004. p. 113. There is a story ascribed to Gautama Buddha in the Lotus Sutra that tells of a traveler who wished to get across a river. In the absence of either a bridge or a ferry, the man proceeds to build a raft. The question the Buddha raises is what the man should do with the raft once he has crossed the river. Should he continue to carry the raft on his back? The obvious answer is that the traveler should abandon the raft once he has traversed the 
agama, bahwa doktrin merupakan suatu alat untuk membantu manusia terbebas dari penderitaan. Pernyataan ini muncul dari suatu cerita dalam salah satu ajaran Buddha bahwa terdapat seorang yang akan menyeberang sungai dan tidak ada bantuan lain selain sebuah rakit. Kemudian pertanyaan yang muncul apakah ketika seorang telah mencapai seberang sungai, rakit tersebut dibawa? Tentunya rakit tersebut akan ditinggalkan. Hal ini tidak jauh berbeda dengan doktrin dari suatu agama yang merupakan alat untuk mengantarkan seseorang mencapai kebebasan. Meskipun demikian, yang perlu dikritisi ketika muncul bahwa rakit ini mulai diperbandingkan dan mulai diklaim ada rakit yang baik dan yang tidak baik. Hal ini sebenarnya mulai terlepas dari fungsi awalnya bahwa rakit tersebut hanya sebuah alat bantu.

Di lain sisi, dalam paradigma Buddhisme bahwa ajaran atau doktrin dari suatu agama merupakan sebuah obat yang digunakan untuk mengatasi penderitaan manusia. Berangkat dari pengalaman Buddha sendiri, bahwa Buddha merupakan dokter yang mampu mengatasi lahir, sakit, tua, dan mati $^{5}$. Parera ${ }^{6}$ juga menandaskan bahwa

"The Buddha has been referred to in the Buddhist tradition as the greatest physician, because the Buddha prescribes medicine for the ultimate illness, Dukkha. Therefore, there is a very close connection between Buddhism and the medicine metaphor. The medical metaphor in Buddhism is not simply a metaphor in words but it is vital aspect of Buddhism. To diagnose of illness, in Buddhism there are three roots that cause illness. There are moha (ignorance), dosa (hatred), and lobha (greed) that make human beings suffer. Therefore, the Buddha searches medicine to medicate suffering."

river. The point of the story is, as traditionally accepted is that it is the same with religious doctrines. They, too, should be abandoned once enlightenment is reached. pp. 112-113

${ }^{5}$ Dhammacakkappavatana sutta is One of the Buddha discourse in the Pali canon. Exactly in the Samyutta Nikaya: S. 5. 421, within Kalupahana, David J. "The Problem of Suffering". A History of Buddhist Philosophy. Delhi: Motilal Banarsidass Publishers, 1992. p. 86.

6 Perera, Lakshman. Buddhism for the New Millennium, United Kingdom, World Buddhist Foundation, 2000. p. 304. 
Untuk merespon dan menggunakan analogi doktrin dari suatu agama sebagai obat pda tataran praktis, Dalai Lama menandaskan bahwa:

"My way to resolve the seeming contradiction between each religion's claim to "one truth and one religion" and the reality of the multiplicity of faiths is thus to understand that in the case of a single individual, there can indeed be only one truth, one religion. However, from the perspective of human society at large, we must accept the concept of "many truths, many religions". To continue with our medical analogy, in the case of one particular patient, the suitable medicine is in fact the only medicine. Nevertheless, clearly that does not mean that there may not be other medicines suitable for other patients". ${ }^{7}$

Pada tataran ini, manusia memahami dunia ini dengan cara yang berbeda. Oleh karena itu, analogi ini sangat relevan dan penting dalam usaha memahami keberagaman agama yang ada di bumi Pancasila ini. Dengan kata lain bahwa berbeda agama mempunyai perbedaan perspektif. Melalui prinsip kesesuaian atau kecocokan, manusia sangat tergantung dari kecocokannya dalam memilih agama. Menanggapi analogi ini Bramantyo menyatakan bahwa:

"This view is very brilliant as it shows how to resolve the conflicting truth claims between different religions. With these views people can respect the belief of his fellow human beings and at the same time still maintain their own belief of their particular traditions. Through the analogy of medicines, it is much easier for people to respect other faiths, however different that may be from one individual tradition, because they understand that different ailments need different medicines. In the same line of thinking, different people need different philosophies that suit their needs and dispositions. From this point of view, people can accept differences among other religious beliefs peacefully"..

Belajar dari analogi tersebut, sebenarnya manusia mempunyai suatu kebebasan dalam memilih dan menjalani kehidupan keagamaan, bahkan bagi

${ }^{7}$ Dalai Lama. Ethics for the New Millennium, Riverhead Book, New York, 1999. pp. 226-227.

8 Bramantyo, Hastho. A thesis The Dalai Lama Response to Religious Diversity. Yogyakarta; Center For Religious and Cross-Cultural Studies, 2008. 
orang yang tidak beragamapun mempunyai hak untuk menjalankan kehidupan rohaninya berdasarkan kecocokan masing-masing individu. Oleh karena itu, manusia mempunyai pilihan dalam menjalankan keagamaannya berdasarkan nilai kecocokan seperti halnya seseorang memilih obat sesuai dengan jenis penyakit yang diidapnya. Dengan kata lain, kita tidak mempunyai alasan yang cukup kuat untuk memaksakan kehendak orang lain untuk menggunakan obat (religious doctrine) yang sama. Menurut hemat saya, bahwa tidak ada suatu jaminan bahwa ketika seluruh umat manusia memeluk satu agama akan hidup dalam keharmonisan. Keanekaragaman agama merupakan suatu nilai yang cukup tinggi karena menambah perspektif kita dalam menghadapi kehidupan. Keanekaragaman agama bak instrument gamelan yang akan menghasilkan suara yang indah, ketika kita memainkannya dengan selaras dan toleransi dengan pemain gamelan yang lainnya. Pemain gamelan sangat menghargai dan memberikan kesempatan untuk pemain yang lain dalam memainkannya.

\section{Concluding Remarks}

Tujuan dari beragama tidak terlepas dari usaha manusia untuk bebas dari derita kehidupan. Seperti halnya tujuan dari seseorang yang berobat berharap untuk terbebas dari penyakit. Menanggapi maslah keanekaragaman agama, doktrin-doktrin dari suatu agama merupakan obat, berbeda doktrin akan mempunyai pengaruh yang berbeda. Namun tujuannya sama bahwa manusia ingin terbebas dari penderitaan, meskipun cara menjelaskan terbebas dari penderitaan tersebut dengan bahasa, konsep, bentuk, dan tradisi yang berbeda. Sebagai contoh ada konsep Moksha dalam Hindu, Nibbana atau Nirvana dalam Buddhisme, dan ada Konsep Tuhan dalam Kriten dan Islam. Maka dari itu, analogi ini akan membantu membuka mata 
kita dalam memahami keanekaragaman agama yang tumbuh berkembang di bumi Pancasila.

Meskipun demikian, perlu disadari bahwa manusia dalam memahami "kesunyataan" masih memiliki keterbatasan. Keterbatasan manusia dalam paradigm Buddhisme dikarenakan manusia masih memiliki kebodohan batin. Kebodohan batin ini dapat berupa ketidakmampuan manusia dalam menrjemahkan dan memahami "kesunyataan" kehidupan. Jika dikaitkan dengan pemikiran dari John Hick bahwa limitation to understand the ultimate reality is language, image, concept, tradition, and different religious experience and religious thought. ${ }^{9}$ Keterbatasan manusia seperti halnya orang buta yang memegang seekor gajah, sehingga mempunyai penafsiran yang berbeda dalam memahami gajah. Bagi orang yang memegang kaki gajah tentu akan mengatakan bahwa gajah seperti pohon yang besar. Begitu juga bagi orang yang memegang telinga gajah akan menjelaskan bahwa gajah seperti kipas yang lebar. Ini merupakan cermin kita bahwa ketika kita belum memahami agama lain, kita tidak berhak untuk mengklaim bahwa agama tersebut salah. Oleh karena itu, dialog yang terbuka akan mengarahkan kita untuk mengembangkan perspektif yang lebih luas dalam memahami keanekaragaman agama.

Pemahaman terhadap keanekaragaman agama sebagai sesuatu yang alami dan wajar akan membantu kita dalam menyikapinya. Hal yang terpenting dari pemahaman ini, kita harus menghormati dan menghargai perbedaan tersebut. Toleransi yang dilakukan tidak hanya superficial, namun diikuti dengan tindakan, ucapan, dan pikiran (beyond tolerance).

${ }^{9}$ Hick, John. "The Conflicting Truth Claims of Different religions". Philosophy of Religion $4^{\text {th }}$ Edition, Prentice-Hall, 1990. p. 109. 